\title{
The heart of darkness
}

\author{
A. H. Petter-Puchner $\cdot$ R. H. Fortelny
}

Received: 3 December 2014 / Accepted: 10 December 2014/Published online: 25 December 2014

(C) Springer-Verlag France 2014

Even for a busy reviewer of highly esteemed surgical journals, it is rare feeling the urge not only to comment but to write an editorial on a submitted manuscript. This has been the case with the work by Suarez-Grau et al. [1]. The form and methodology are sound, the style is flawless and the results are original but far from spectacular. It is something different in that experimental work on synthetic absorbable meshes with antibiotic coating to be used in contaminated wound fields, which immediately rang a bell.

By designing the study in this specific way the authors blended three of the most acute issues in current hernia research. In short:

- Will synthetic absorbable meshes replace biologics and should they widely be used for hernia repair?

- What kind of modifications to existing mesh materials can be expected to better target the needs and requirements of modern hernia surgery (e.g., antibiotics, new antiadhesive compounds, new agents for selffixation...)

And most importantly

- Will any consensus be reached if meshes (regardless if synthetic or biologic) should be used in contaminated wound fields at all?

\footnotetext{
A. H. Petter-Puchner $(\bowtie) \cdot$ R. H. Fortelny

Hernia Center at the Department of General, Visceral and Oncological Surgery, Wilhelminenspital, Montleartstr. 37, 1171 Vienna, Austria e-mail: alexander.petter@trauma.lbg.ac.at; alexander.petter-puchner@wienkav.at

A. H. Petter-Puchner

Ludwig Boltzmann Institute for Experimental and Clinical Traumatology, Austrian Cluster for Tissue Regeneration, Donaueschingenstr. 13, 1200 Vienna, Austria
}

It is not within the scope of this editorial to provide satisfying answers to any of these questions. However, it seems clear that the authors of the article have hit the "heart of darkness", the area of the most controversial debates and the fiercest pros and cons.

Let us begin with the provocative question what biologic meshes could contribute to hernia repair in the past decade? Astonishingly little, given the fact that there is still little evidence, which would support their use. The products and the companies behind them merely survive on the assumption that they outperform synthetic meshes in contaminated wound fields. Interestingly enough, this mantralike promise could not been validated beyond doubt, yet [2].

Taking advantage of the increasing disbelief and disappointment in biologic meshes, absorbable synthetic materials are now promoted as an alternative [3]. They are significantly cheaper and preliminary studies suggest good tissue integration, but different issues arise from this development. Most hernia surgeons and researchers will struggle to define the patient population in which it was safe to implant absorbable meshes without an increased risk of recurrences. This will remain a hard task, bearing in mind that we still cannot reproducibly distinguish patients suffering from ventral hernias due to a technical error in midline closure from those striven by a disorder of collagen formation. In the later all would agree that an absorbable mesh (as well as a biologic?) might not be the right choice.

Coming to the field of mesh coating, the combination of mesh with antibiotics is not new and we have seen a trend toward antibiotically impregnated suture materials in our ORs (although even here recent literature provides controversial data) $[4,5]$. In hernia meshes, it is still not a common property. It should not be forgotten that this 
practice raises interesting questions, like putting a drainage to the mesh compartment and how this would affect the local concentration of the drug.

The underlying reason for antibiotic coating is the desire (and need?) of hernia surgeons to place meshes in contaminated or even dirty wound fields. The authors of this editorial feel that this is one of the most important issues demanding clarification and recommendation. We sincerely believe that in most cases it is avoidable to use a mesh under such conditions if clinicians and patients can endure a lengthy treatment regimen [6]. We emphasize that a clean wound situation should be achieved before a final closure is attempted (this has been possible in most patients even after disastrous courses of closing an open abdomen after the prolonged treatment of secondary peritonitis). Repair of the hernia was performed when the local situation has improved. It is only then, that extensive repairs with or without the assistance of the plastic surgeon can safely be performed and excellent long-term results achieved. None of the famed studies on biologic matrices can contradict this statement. Literature and own experience also indicate that vacuum-assisted closure $\left(\mathrm{VAC}^{\circledR}\right)$ therapy is a useful option for salvaging infected mesh [7].

Although we appreciate and respect different approaches to this matter it must be clear that it was the promise of the superior performance of biologics in dirty wounds that made many surgeons change their routine and not the pure medical necessity. The old saying "there is no short cut in surgery" depicts the situation adequately_opting for a quick fix in challenging hernia repairs may set back the patients by years if not a life time if the primary closure strategy fails.

In summary, the authors of the article should be thanked for their sensitivity to shape a work that beyond the data contained contributes to the reflection on current proceedings and to the quest to deliver the best treatment strategies and implants to our patients.

\section{References}

1. Suárez-Grau JM, Morales-Conde $\mathrm{S}$, González Galán V, Martín Cartes JA, Docobo Durantez F, Padillo Ruiz FJ. Prevention of surgical infection using reabsorbable antibacterial suture (Vicryl Plus) versus reabsorbable conventional suture in hernioplasty. An experimental study in animals

2. Itani KM, Rosen M, Vargo D, Awad SS, Denoto G 3rd, Butler CE, RICH Study Group (2012) Prospective study of single-stage repair of contaminated hernias using a biologic porcine tissue matrix: the RICH Study. Surgery 152(3):498-505. doi:10.1016/j.surg.2012.04.008

3. Martin DP, Badhwar A, Shah DV, Rizk S, Eldridge SN, Gagne DH, Ganatra A, Darois RE, Williams SF, Tai HC, Scott JR (2013) Characterization of poly-4-hydroxybutyrate mesh for hernia repair applications. J Surg Res 184(2):766-773

4. Guillaume O, Lavigne JP, Lefranc O, Nottelet B, Coudane J, Garric X (2011) New antibiotic-eluting mesh used for soft tissue reinforcement. Acta Biomater 7(9):3390-3397. doi:10.1016/j. actbio.2011.05.009

5. Diener MK, Knebel P, Kieser M, Schüler P, Schiergens TS, Atanassov V, Neudecker J, Stein E, Thielemann H, Kunz R, von Frankenberg M, Schernikau U, Bunse J, Jansen-Winkeln B, Partecke LI, Prechtl G, Pochhammer J, Bouchard R, Hodina R, Beckurts KT, Leißner L, Lemmens HP, Kallinowski F, Thomusch O, Seehofer D, Simon T, Hyhlik-Dürr A, Seiler CM, Hackert T, Reissfelder C, Hennig R, Doerr-Harim C, Klose C, Ulrich A, Büchler MW (2014) Effectiveness of triclosan-coated PDS Plus versus uncoated PDS II sutures for prevention of surgical site infection after abdominal wall closure: the randomised controlled PROUD trial. Lancet 384(9938):142-152

6. Fortelny RH, Hofmann A, Gruber-Blum S, Petter-Puchner AH, Glaser KS (2014) Delayed closure of open abdomen in septic patients is facilitated by combined negative pressure wound therapy and dynamic fascial suture. Surg Endosc 28(3):735-740. doi:10.1007/s00464-013-3251-6

7. Chatzoulis G, Chatzoulis K, Spyridopoulos P, Pappas P, Ploumis A (2012) Salvage of an infected titanium mesh in a large incisional ventral hernia using medicinal honey and vacuum-assisted closure: a case report and literature review. Hernia 16(4):475-479 